\title{
PENGGAMBARAN DUNIA DALAM NOVEL PERJALANAN 99 CAHAYA DI LANGIT EROPA
}

\author{
Anis Mashlihatin \\ S2 Ilmu Sastra FIB UGM \\ E-mail: anismashlihatin@gmail.com
}

\begin{abstract}
Abstrak
Tulisan ini membahas pengamatan objektif dan subjektif yang digunakan oleh penulis dalam menggambarkan dunia ketika ia melakukan perjalanan. Dunia di sini tidak hanya mengenai lanskap atau tempat-tempat, tetapi juga pada orang-orang. Dalam pengamatan objektif, penulis mengambil jarak dengan dunia yang digambarkannya. Sebaliknya, pengamatan subjektif menekankan keterlibatan personal penulis terhadap dunia yang diceritakan. Dalam penelitian ini, terlihat bahwa baik terhadap tempat maupun orang-orang, pengamatan yang subjektif lebih dominan dibandingkan dengan pengamatan objektif. Pengamatan selalu bergerak dari yang objektif menuju subjektif. Beberapa tempat digambarkan dengan objektif, tetapi kemudian bergeser pada yang subjektif. Pengamatan subjektif eksplisit lebih dominan dibandingkan dengan yang implisit. Namun, meskipun dalam tataran kuantitas lebih sedikit, subjektif yang implisit ini memberikan pengaruh yang signifikan.
\end{abstract}

Kata kunci: objektif, subjektif, perjalanan

\begin{abstract}
Thispaper discussed about the objective and the subjective observations which are used by the writer in representing the world when the writer is traveling. World is not just merely a landscape or places, but there is also people. Through objectivity point of view, the writer is taking distance with the world which is described. On the contrary, subjective observation emphasizes the personal involvement of the writer towards the described world. In this research, we can see in both places and people, subjective observation is more dominant than the objective observation. Observation always sets off from the objective point of view to the subjective point of view. Some places are described objectively, but then it shifted into subjective. Explicit subjective observation is more dominant than the implicit one. However, even if the quantity is lesser, the implicit subjectivity gives more significant influence.
\end{abstract}

Keywords: objective, subjective, travel

\section{Pendahuluan}

Beberapa tahun terakhir ini bermunculan buku cerita perjalanan yang ditulis oleh orang Indonesia. Hal itu, misalnya, dapat dilihat dari terbitnya lima seri buku The Naked Traveler (2007) karya Trinity yang naik cetak berulang kali. Kemudian muncul novel Negeri van Oranje (2009) yang ditulis Wayhuningrat dkk. Disusul kemudian catatan perjalanan Agustinus Wibowo yang dibukukan menjadi trilogi, yaitu Selimut Debu (2010), Garis Batas: Perjalanan di Negeri-Negeri Asia Tengah (2011), dan Titik. Nol: Makna Sebuah Perjalanan (2012). Buku-buku tersebut mendapat respons yang sangat bagus di kalangan pembaca. Selanjutnya, pada 2011 terbit novel 99 Cahaya di Langit Eropa karya
Hanum Salsabiela Rais dan Rangga Almahendra serta 9 Summers 10 Autumns Dari Kota Apel ke The Big Apple karya Iwan Setyawan; kemudian secara berturut-turut pada 2013 sebelas novel yang bertajuk "Setiap Tempat Punya Cerita" diterbitkan oleh Gagas Media dan Bukuné, dan masih banyak lagi.

Secara garis besar, cerita-cerita perjalanan itu mengisahkan orang-orang Indonesia dengan berbagai kepentingan melakukan perjalanan ke luar negeri, terutama di negara-negara Eropa. Mereka mengunjungi tempat-tempat yang baru dan asing, mengalami perjumpaan, berinteraksi, dan terlibat dengan orang-orang dari berbagai penjuru dunia. Mereka, yang sebelumnya terpisah secara geografis dan historis, bertemu 
dalam satu momen yang menempatkan mereka pada situasi dan persoalan-persoalan tertentu.

Dari berbagai cerita perjalanan yang terbit itu, penelitian ini akan berfokus pada novel 99 Cahaya di Langit Eropa (2011). Di samping karena novel ini dianggap mewakili cerita-cerita perjalanan ke Eropa (yang mendominasi ceritacerita perjalanan yang bermunculan itu), novel ini dipilih karena dianggap memberikan wacana yang lebih kompleks dibandingkan dengan novel-novel sejenis yang terbit pada masanya. Novel 99 Cahaya di Langit Eropa, sebagai cerita perjalanan, tidak hanya menyuguhkan berbagai gambaran mengenai tempat-tempat yang asing bagi penulis. Mereka juga berinteraksi dengan orang-orang Eropa dan dihadapkan dengan berbagai realitas kehidupan orang Eropa dan non-Eropa. Selain itu, novel ini juga mendapatkan respons yang antusias dari pembaca dan sempat difilmkan pada tahun 2013. Novel ini menceritakan pengalaman pribadi si penulis ketika berada di Eropa (Austria) selama tiga tahun, 2008-2011. Selain di Austria, penulis juga melakukan perjalanan ke berbagai negara Eropa lain, seperti, Prancis, Spanyol, dan Turki.

Novel ini setidaknya memuat tiga hal penting, yaitu dunia, diri, dan yang lain (the other). Tulisan ini secara khusus akan berfokus pada bagaimana penulis menggambarkan dunia. Gambaran tentang dunia dapat dilihat ketika penulis mendeskripsikan setiap tempat yang dikunjungi dan orang-orang yang ditemuinya. Dalam perjalanannya itu, penulis mengunjungi tempat yang cukup luas, mencakup Wina, Paris, Cordoba, Granada, Istanbul, dan Mekkah. Tempat-tempat itu masih dapat dipecah menjadi bagian kecil, misalnya Bukit Kahlenberg, Sungai Danube, beberapa museum di Austria dan Prancis, istana, masjid, gereja, jalan raya, bandara, dan masih banyak lagi. Sementara itu, orang-orang yang ditemui oleh penulis juga beragam, mulai dari orang Eropa, para migran, orang-orang Islam, non-Islam, Yahudi, para turis, dan lain-lain.
Pada bagian penggambaran tentang dunia, penelitian ini akan melihat strategi apa yang dominan digunakan oleh penulis: objektif atau subjektif. Selanjutnya, dari kedua strategi tersebut akan dilihat pola yang terbentuk dari penggambaran tempat dan orang-orang; pada momen apa penulis menggunakan strategi objektif dan subjektif; dan apakah penggambaran selalu bergerak dari objektif menuju subjektif.

\section{Penggambaran Dunia dalam Sastra Perjalanan}

Tidak mudah untuk memberikan definisi atau batasan yang jelas tentang apa itu perjalanan dan sastra perjalanan. Istilah sastra perjalanan adalah label generik yang sangat luas dan seringkali membingungkan. Sastra perjalanan selalu menjalin hubungan yang kompleks dan membingungkan dengan sejumlah genre yang terkait erat dengannya (Raban dalam Thompson, 2011: 11). Salah satu definisi sederhana yang dapat diberikan tentang perjalanan adalah negosiasi antara diri dan 'yang lain' yang dibawa oleh perpindahan dalam ruang (Thompson, 2011: 9). Dengan demikian, sastra perjalanan adalah hasil dari pertemuan antara diri dan 'yang lain'. Bertolak dari definisi tentang perjalanan tersebut, sastra perjalanan kemudian dipahami sebagai laporan perjalanan tentang dunia yang lebih luas yang dilakukan oleh orang asing di tempat yang asing atau belum diketahui (Thompson, 2011: 10).

Dalam sebagian besar bentuknya, menurut Thompson (2011: 62), prinsip utama sastra perjalanan adalah untuk melaporkan/ menggambarkan dunia yang lebih luas dan menyebarluaskan informasi tentang orang dan tempat yang asing. Namun, ada banyak lapisan mediasi antara dunia yang sebagaimana adanya dan dunia seperti apa yang selanjutnya dipaparkan dalam sastra perjalanan. Peristiwa dan kejadian yang ditemui dalam perjalanan penulis selalu hadir kepada pembaca dalam bentuk yang disaring, dibiaskan pertama melalui 
kesadaran pengamatan penulis dan kedua melalui tindakan penulisan, peralihan dari "pengalaman perjalanan" ke dalam “teks perjalanan".

Hal tersebut melibatkan proses yang selektif dimana penulis mengutamakan beberapa aspek dari pengalaman perjalanannya atas yang lain, sesuai dengan preferensi kepenulisannya. Akibatnya, bentuk sastra perjalanan yang berusaha untuk akurat dan objektif itu hanya menawarkan gambaran parsial dari dunia dan gambaran tidak lengkap yang jauh dari realitas yang kompleks. Oleh karena itu, lanjut Thompson (2011: 63), sastra perjalanan tentu mendistorsi dunia bahkan akan terbawa ke dalam pandangan penulisnya.

Akibatnya, penggambaran penulis tentang dunia itu memiliki dua arah yang berlawanan, yaitu penggambaran secara objektif dan subjektif. Dalam penggambaran objektif, penulis menginformasikan apa-apa yang dilihat atau didengar secara apa adanya. Penggambaran yang objektif membatasi narasi kekuasaan pengarang sebagai subjek, tetapi berusaha membatasi laporan yang kesannya anekdot atau impresionistik (Thompson, 2011: 84). Sebaliknya, dalam penggambaran subjektif penulis menyajikan informasi-informasi yang mengindikasikan keterlibatan diri, responsrespons emosional, dan penilaian penulis. Strategi objektif mensyaratkan keberjarakan. Sebaliknya, strategi subjektif mensyaratkan keterlibatan penulis.

Meskipun demikian, baik penggambaran yang objektif maupun yang subjektif tidak pernah benar-benar berlawanan. Penggambaran yang subjektif harus tetap didasarkan pada yang objektif, setidaknya untuk meyakinkan pembaca. Menurut Thompson (2011: 63), sastra perjalanan harus memiliki acuan pada realitas tempat dan budaya yang digambarkan penulis sehingga perjalanannya bukan hanya sebuah fiksi atau fabrikasi. Keseimbangan antara fakta dan fiksi ini menjadikan pembaca bergulat dengan pertanyaan-pertanyaan yang berkaitan dengan validitas pengetahuan yang ditawarkan oleh sastra perjalanan. Untuk itu, terdapat berbagai strategi yang digunakan oleh penulis guna menghindari kekhawatiran pembaca terhadap validitas tulisan yang dibacanya. Salah satu strategi yang digunakan penulis adalah cara pandang orang pertama yang sering digunakan karena melayani fungsi retoris yang menandai teks sebagai pernyataan dari seseorang yang benar-benar hadir pada saat kejadian dijelaskan. Hal itu adalah sarana kunci untuk menyatakan akurasi dan pentingnya penggambaran mereka.

\section{Penggambaran Objektif dalam 99 Cahaya di Langit Eropa}

Penggambaran objektif yang digunakan oleh penulis setidaknya dapat dibagi menjadi dua, yaitu yang jarak pandangnya jauh dan yang berjarak pandangnya dekat. Dalam jarak pandang yang jauh biasanya penulis menggambarkan dunia dengan sekilas dan tidak detail, sedangkan pada jarak pandang dekat memungkinkan penulis memberikan gambaran yang detail dan menyeluruh. Penggambaran dalam jarak pandang jauh itu, misalnya, terlihat dalam kutipan berikut.

"Dari kejauhan aku melihat puncak
menara gereja Stephansdom yang tinggi
menjulang dan berwarna hitam legam.
Pilar-pilar atasnya yang runcing bak
jarum-jarum raksasa yang menantang
langit. Stephanplatz, sebuah distrik
perbelanjaan terbesar di Wina, mengambil
nama besar katedral ini" (Salsabiela dan
Rangga, 2011: 70-71).

Kutipan di atas adalah gambaran penulis mengenai gereja Stephansdom yang ada di Wina. Dalam jarak pandang yang jauh, gambaran yang dimunculkan penulis tentang gereja tersebut tidaklah detail. Yang menjadi titik perhatian penulis pada gereja Stephansdom hanya pada menaranya. Bagian-bagian gereja yang lain diabaikan. Selain gereja tersebut, ada dua gereja yang dikunjungi oleh penulis, yaitu gereja St Charles dan gereja St Joseph. Sama seperti gereja Stephansdom, penggambaran 
terhadap gereja St Charles hanya berfokus pada menara yang dilihat dari kejauhan. Pada dua gereja itu, penulis tidak masuk ke dalam ruangannya. Namun, ketika penulis masuk ke dalam ruang gereja St Joseph, tidak terdapat gambaran eksterior maupun interior mengenai gereja itu. Gambaran seperti itu mengasumsikan bahwa penulis tidak memiliki ketertarikan terhadap apa yang dilihatnya sehingga ia hanya menyajikannya secara sambil lalu.

"Penggambaran jarak pandang jauh juga terlihat ketika penulis menggambarkan lanskap.

Indah sekali. Paris pada malam hari seperti hamparan permadani cahaya. Kerlap-kerlip keemasan terpancar dari jutaan lampu gedung, rumah-rumah, dan mobil yang lalu-lalang. Semuanya begitu terstruktur, tidak morat-marit. Lautan cahaya mini yang berpendar menembus pekatnya atmosfer malam Eropa" (Salsabiela dan Rangga, 2011: 126-127).

Penggambaran di atas dilakukan penulis ketika dirinya masih berada di atas pesawat. Dalam jarak pandang yang jauh itu, Paris terlihat sebagai kota yang teratur dan penuh cahaya gemerlapan. Padangan yang demikian ini berubah ketika penulis melakukan pengamatan dari jarak yang dekat.

"Selain gereja dan lanskap, terdapat juga gambaran jarak jauh tentang istana. Dari kejauhan, kami tidak melihat Al-Hambra sebagai istana molek seperti yang digembar-gemborkan buku-buku wisata, melainkan sebuah benteng pertahanan yang dikitari menara-menara pengawas musuh. Sebuah bangunan yang seakan dihantui oleh ketakutan akan penaklukan. Ya, penaklukan oleh kerajaan Kristen Spanyol yang terus menggusur wilayah kesultanan Islam" (Salsabiela dan Rangga, 2011: 295).

Meskipun sebelumnya telah mendapatkan pengetahuan tentang istana Alhambra dari bukubuku perjalanan, penulis tetap menggambarkan apa yang diinderanya secara langsung. Dalam hal ini, penulis berupaya untuk tetap objektif. Namun, pandangan yang objektif tersebut pun tidak penuh karena penulis melibatkan penafsiran terhadapnya. Ia menganggap bahwa istana tersebut seakan dihantui oleh ketakutan akan penaklukan. Dalam pernyataan itu, secara tersirat terdapat kekecewaan dan kesedihan penulis atas apa yang dilihatnya di istana itu. Selain itu, gambaran istana itu pun hanya sekilas, tidak rinci.

Dalam novel ini, penggambaran dengan jarak pandang jauh terlihat minim. Sebaliknya, baik terhadap tempat dan orang-orang, penggambaran didominasi dengan pengamatan objektif jarak pandang dekat. Perhatikan kutipan berikut.

"Diafragma kameraku menangkap sebuah objek yang membuatku bertanyatanya. Sederhana, tetapi dia memberikan pengaruh besar terhadap horizon pemandangan kota Wina. Sebuah sungai yang membelah kota Wina menjadi dua. Aku baru sadar, inilah sungai yang terkenal itu. Donau atau Danube. Sungai yang menginspirasi Johann Strauss menciptakan lagu waltz The Blue Danube" (Salsabiela dan Rangga, 2011: 30-31).

"Matahari semakin menenggelamkan diri ke peristirahatannya. Ekor sinarnya yang berwarna semburat jingga terlihat begitu anggun. Suguhan lukisan alam yang semakin indah pada senja hari. Dari mataku aku mengindera 3 horizon panorama. Paling atas adalah langit gelap dan matahari yang terbenam. Di tengah adalah bangunan-bangunan tinggi bercahaya yang kuyakini sebagian besar adalah gedung pencakar langit di kompleks markas PPB, gereja, dan menara pemancar. Paling bawah adalah sungai Danube, simfoni gemericik airnya bisa terdengar dari atas Bukit Kahlenberg. Komposisi pemandangan yang langka di mataku" (Salsabiela dan Rangga, 2011: 31-32).

Kedua kutipan di atas memperlihatkan gambaran objektif penulis yang digunakan untuk menggambarkan lanskap yang ada di Bukit Kahlenberg. Kutipan yang pertama 
adalah objektif jarak pandang dekat dengan mediasi kamera. Berdasarkan penuturan penulis, dapat diketahui bahwa Sungai Danube membelah kota Wina menjadi dua. Penulis pun mampu menggambarkan bahwa sungai tersebut bening, alirannya terkadang tenang dan terkadang bercipratan. Kutipan selanjutnya adalah penglihatan penulis tanpa menggunakan mediasi. Baik dengan mediasi kamera maupun tidak, penulis menggambarkannya dengan detail.

Tidak hanya pada lanskap, gambaran semacam itu juga terlihat ketika penulis menggambarkan eksterior dan interior pada masjid, museum, serta istana. Sebagai contoh, perhatikan kutipan berikut.

"Dari seberang jembatan rel U-Bahn aku bisa melihat masjid bercorak hijau putih memberi aksen pemandangan musim panas di tepi Sungai Danube" (Salsabiela dan Rangga, 2011: 110).

"Mataku melihat-lihat sekitar masjid itu. Masjid yang sangat sederhana. Terdiri atas dua tingkat, ditutupi permadani merah cerah dan dihiasi beberapa jendela" (Salsabiela dan Rangga, 2011: 115).

Pada kutipan diatas, penulis seolah melihat masjid dari arah yang jauh. Akan tetapi, posisi tersebut tidak berlangsung lama karena penulis bergerak mendekati masjid tersebut. Semakin dekat, deskripsi penulis terhadap masjid itu semakin detail. Selain itu, penulis tidak hanya berhenti di luar masjid, ia pun memasukinya. Bagian-bagian yang terdapat di dalam ruang masjid itu pun digambarkannya dengan detail. Di Wina, penulis merasa sulit menemukan masjid sehingga antusiasmenya terlihat ketika dia menemukan masjid. Penggambaran tentang masjid juga terlihat pada masjid Besar Paris dan Masjid Biru di Istanbul.

"Masjid ini dikelilingi tembok berwarna putih dengan genteng hijau dan pintupintu lengkung khas masjid. Tepat di samping menara masjid itu aku melihat pintu gerbang utama yang di atasnya terpasang lambang bulan sabit raksasa. Di dalam kompleks itu sebuah kolam air mancur menyambut kedatangan kami. Sayup-sayup aku mendengar suara adzan ashar berkumandang dari menara itu" (Salsabiela dan Rangga, 2011: 189).

Gambaran masjid ini objektif, meskipun tidak detail dan diselingi ungkapan-ungkapan kekaguman. Selain kutipan di atas, tidak terdapat keterangan lain tentang masjid ini. Penulis tidak memberikan keterangan yang jelas apa yang dimaksud dengan "artistik" dan "kental dengan nuansa Islam".

Dalam uraian sebelumnya telah disinggung bahwa gereja seringkali dipandang dari jarak pandnag jauh. Satu-satunya gereja yang dipandang dari jarak yang dekat oleh penulis adalah Notre Dame. Penulis memang sangat mengagumi gereja ini. Akan tetapi, ia tidak memasuki ruang gereja sehingga penggambarannya hanya sebatas yang dapat dilihat dari luar.

"Aku yang dari tadi sangat terpesona oleh kemegahan ukuran gereja raksasa ini sama sekali tidak memperhatikan bentuk pintu masuk di depan kami. Ada tiga gerbang utama sebagai pintu masuk dan keluar katedral ini. Dan setelah kami perhatikan, ketiganya berbentuk kubah lengkung, sangat mirip dengan kekhasan bangunan yang sangat kami kenal: masjid" (Salsabiela dan Rangga, 2011: 199).

Mezquita di Cordoba adalah bangunan yang semula berupa masjid, tetapi kemudian dialihfungsikan sebagai katedral/gereja. Penulis menggambarkannya sebagai berikut.

"Begitu kami menginjakkan kaki ke kompleks Mezquita, sebuah kolam dengan pancuran berundak-undak adalah keindahan yang pertama kami lihat di Masjid Katedral ini. Air mancur di pelataran masjid, seperti yang kulihat di masjid Paris, namun ukurannya jauh lebih besar. Airnya yang melompat-lompat dari ujung pancuran seperti menyapu dahaga kami dari panasanya matahari" (Salsabiela dan Rangga, 2011: 254). 
“...Pilar-pilar dalam bangunan seluas $24.000 \mathrm{~m}^{2}$ itu mengingatkanku pada gaya bangunan yang sama di Nabawi. Pilar-pilar penyangga Mezquita itu beraksen merah dan putih, ada ukiran dan pahatan yang sangat indah di bagian atasnya-antarpilar dihiasi lengkungan yang sangat khas. Di tengah setiap blok yang terbentuk dari 856 pilar itu terdapat lampu-lampu gantung dengan tali yang menjulur panjang dari atap yang sangat tinggi. Sejauh mata memandang, pilarpilar ini seperti ribuan pohon palem yang ditanam berjajar dengan sangat teratur. Aku mendapati pilar-pilar in begitu kokoh dan sejuk bila disentuh" (Salsabiela dan Rangga, 2011: 257).

Selanjutnya penggambaran berjarak pandang dekat juga dapat dilihat ketika ia menggambarkan istana dan museum.

"Begitu masuk pintu utama ruang istana, mata kami langsung disuguhi ruang-ruang dengan dinding berlapis kuning emas, berpermadani merah marun, berlangitlangit coretan kanvas. Belum lagi ornamen dinding ukiran yang detailnya sangat njlimet dan ruwet. Suara alas parket kayu yang berderik-derik setiap kami melangkahkan kaki menambah atmosfer kekunoan Schoenbrunn" (Salsabiela dan Rangga, 2011: 65).

"Museum Wina sekilas tampak berbeda dengan arsitektur museum kebanyakan. Bangunannya terlalu modern, tidak seperti bangunan museum pada umumnya yang bergaya klasik rococo, gaya bangunan Eropa pada umumnya. Lokasinya terletak tepat di belakang gereja St. Charles yang memiliki atap berbentuk kubah raksasa dengan banyak ornamen emas" (Salsabiela dan Rangga, 2011: 70).

Kutipan pertama adalah ketika penulis memasuki Istana Schoenbrunn, sedangkan kutipan kedua dan seterusnya adalah ketika Hanum mengunjungi Wien Stadt Museum atau museum Kota Wina. Hanum lebih memberikan perhatian pada sisi interior istana daripada eksteriornya. Gambaran dinding, lantai, serta langit-langit istana disajikan secara menyeluruh dan detail. Hal yang sama juga diperlihatkan pada musem Kota Wina.

Penulis mengungkapkan bahwa arsitektur Wien Stadt museum terlalu modern dan tidak seperti bangunan museum pada umumnya. Akan tetapi, penulis tidak memberikan penjelasan lebih lanjut mengenai pernyataannya itu, sehingga gambaran eksterior bangunan itu tidak dapat diketahui. Namun, penulis memberikan perhatian pada bagian interior. Interior dipandang dengan jarak yang dekat dan dideskripsikan dengan detail. Meskipun demikian, hanya ruangan tertentu yang akhirnya menjadi perhatian utama penulis, yaitu ruangan yang terdapat di lantai dua. Di lantai itu terdapat satu objek yang diamati secara intens oleh penulis, yaitu sebuah lukisan (yang akan dipaparkan pada bagian selanjutnya).

Hal yang sama juga dapat dilihat pada museum Schatzkammer dan museum Louvre. Beberapa objek yang terdapat di dalam museum Sachatzkammer disuguhkan secara menyeluruh. Pada museum Louvre yang ada di Paris, awalnya penulis mendeskripsikannya dengan jarak pandang yang jauh, tetapi penulis kemudian bergerak mendekat sehingga pengamatannya pun lebih banyak berjarak pandang dekat. Dalam jarak pandang yang dekat itu, gambaran penulis tentang museum Louvre tampak pada kutipan berikut.

"Bangunan itu memiliki tiang-tiang penyangga begitu solid. Bagian tengahnya dipahat dengan relief yang sangat elegan. Di puncak bangunan bertengger kubahkubah yang menantang matahari. Jejeran bangunan itu melingkar membentuk paviliun-paviliun bercabang dengan pelataran sangat luas. Namun, ada pemandangan ganjil yang kulihat tepat di tengah pelataran kompleks Museum Louvre itu. Bangunan piramida gelas raksasa modern sekilas merusak harmoni kemegahan yang tersaji di depanku." 


\begin{abstract}
"Setelah lama kuperhatikan, justru struktur piramida gelas itulah yang menjadi pusat energi di kompleks museum ini. Paviliun raksasa yang mengelilinginya bagai tertunduk hormat menghadap sang piramida. Turis yang berada di depan kami langsung berteriak kegirangan menyaksikan pemandangan ini. Piramida itu begitu memikat hingga turis tadi berlonjak-lonjak seperti melihat harta karun".
\end{abstract}

\begin{abstract}
"Mata kuedarkan kembali ke langitlangit aula yang mengumbar ribuan gelas berbentuk belah ketupat berlian. Berkali-kali jepretan menghambur dari kameraku. Bangunan ini memang genius. Dengan atap semacam itu, sorot cahaya matahari tak perlu menelikung lewat jendela-jendela, tetapi bisa langsung masuk ke dalam bangunan di bawah tanah. Membuat para pengunjung betah berlama-lama dalam bangunan itu tanpa merasakan kegelapan" (Salsabiela dan Rangga, 2011: 146).
\end{abstract}

Gambaran eksterior museum Louvre pun disajikan dengan detail. Dalam kutipan itu juga dapat diketahui adanya perubahan jarak pandang, yaitu dari yang dekat menjadi sangat dekat. Pada jarak yang sangat dekat itu, terjadi perubahan penilaian. Awalnya penulis mengatakan bahwa piramida gelas adalah pemandangan ganjil dan merusak harmoni kemegahan. Namun, penilaian tersebut kemudian berubah dengan cepat menjadi pusat energi yang kompleks di museum ini. Perhatian penulis pun serta merta beralih ke piramida gelas tersebut. Dari sisi eksterior, gambaran-gambaran yang diberikan oleh penulis terhadap museum ini lebih detail dibandingkan dengan museum-museum dan bangunan yang dikunjungi sebelumnya. $\mathrm{Hal}$ ini mengindikasikan bahwa penulis memiliki ketertarikan lebih dengan tempat tersebut, sehingga mampu menyita perhatiannya.

Penggambaran yang objektif berjarak pandang dekat juga terlihat ketika penulis menggambarkan Hagia Sophia. Hagia Sophia yang berada di Istanbul adalah katedral yang dijadikan masjid, tetapi kemudian difungsikan sebagai museum. Pengamatan yang dilakukan penulis terhadap interior Hagia Sophia ini dilakukan dengan jarak pandang yang dekat, intens, dan deskripsi yang detail.

Secara keseluruhan dapat dikatakan bahwa penggambaran yang detail terhadap masjid, istana, dan museum ini mengasumsikan ketertarikan dan kekaguman penulis terhadap objek yang digambarkannya. Ketertarikan itulah yang menyebabkan penulis tidak dapat melepaskan ungkapan-ungkapan kekagumannya. Beberapa tempat digambarkan dengan pengamatan jarak juah dan dekat, tetapi pengamatan jarak dekat terlihat lebih dominan.

Selanjutnya, penulis tidak hanya memberikan perhatian pada sisi interior dan eksterior pada tempat-tempat yang dikunjungi dan benda-benda yang ditemuinya, tetapi juga pada orang-orang yang ditemuinya. Perhatikan kutipan berikut.

"Jemaah yang sebagian besar beruban alias berusia lanjut tampak khidmat mendengarkan khotbah dan sesekali menyanyikan lagu bersama. Beberapa rombongan jemaah mengalir berdatangan dan langsung mengambil tempat" (Salsabiela dan Rangga, 2011: 34).

"Ternyata banyak turis yang juga kedinginan seperti kami. Masuk ke gereja bukan untuk berdoa, melainkan karena tak kuat lagi menahan dingin. Gereja menjadi penyelamatnya. Para turis berdiri di area luar misa dan tanpa malu-malu menjepret objek-objek menarik dalam gereja. Hal ini boleh dilakukan dengan satu syarat, tanpa blits." (Salsabiela dan Rangga, 201: 35).

Kutipan yang pertama adalah gambaran mengenai orang-orang yang ditemui penulis di gereja, yaitu para jemaah yang sedang melakukan peribadatan. Gambaran terhadap orang-orang ini dilakukan dengan pengamatan jarak pandang dekat dan dideskripsikan dengan detail. Penulis menggambarkannya mulai dari perkiraan usia hingga gerak-gerik mereka di dalam gereja. 
Ketika penulis tidak memperhatikan detail bangunan yang ada di gereja Saint Joseph, penulis memperhatikan orang-orang yang berada di dalamnya. Perhatian penulis yang lebih dominan terhadap orang-orang yang memasuki gereja dibandingkan dengan perhatiannya terhadap gereja itu sendiri menegaskan bahwa dirinya tidak begitu mementingkan gambaran detail gereja. Kutipan yang kedua adalah orang-orang yang juga berada di gereja Saint Joseph. Mereka adalah para turis yang berlindung di gereja karena diserang oleh hawa dingin perbukitan. Meskipun gambarannya dilakukan dengan jarak pandang dekat, gambaran terhadap para turis tersebut hanya sekilas.

Selanjutnya adalah gambaran orangorang yang berada di dalam masjid besar Wina dan orang-orang di tepi Sungai Danube (yang berada di seberang masjid).

"Beberapa orang masih duduk-duduk di dalam masjid. Ada yang mengaji, ada yang berbincang-bincang, ada yang berdiam diri dan bermunajat dengan Sang Pencipta" (Salsabiela dan Rangga, 2011: 115).

"Aku menuruni tangga U-Bahn. Sebuah pemandangan yang ironis tampak di hadapanku. Muncul pria-pria berbaju gamis, berjenggot dan berkopiah yang menenteng sajadah atau tasbih dari U-Bahn tadi. Termasuk Rangga, kulihat dia berlari-lari kecil dari jauh. Mereka semua menuju masjid yang berdiri tepat di sebelah tepian Danube. Tapi untuk menuju masjid, itu bukan perkara mudah. Di pelataran bawah stasiun U-Bahn, keramaian lain telah menyambut kehadiran jemaah Jumat. Mereka adalah para manusia berbaju minim-atau minim sekali mendekati telanjang-lakilaki maupun perempuan" (Salsabiela dan Rangga, 2011: 111).

"Diantaramerekaadayangbercengkerama memadu kasih. Yang jomblo atau kesepian hanya bisa memandangi bebek dan angsa yang berenang-renang. Yang serasa piknik akan membawa bekal makanan dan minuman, lalu membaca buku di bawah rindangnya pepohonan.
Tak jarang kawanan bebek dan angsa tadi menyambangi orang-orang itu untuk minta makan. Lalu anjing-anjing piaraan orang-orang itu serta merta menyerang mereka; seakan-akan mereka adalah pesaing hewan kesayangan sang majikan" (Salsabiela dan Rangga, 2011: 112).

Kutipan pertama adalah orang-orang yang berada di dalam masjid. Dengan sendirinya dapat diidentifikasi bahwa mereka adalah orang-orang muslim. Kutipan yang kedua dan seterusnya adalah orang-orang yang berjemur di tepi Sungai Danube. Secara tidak langsung penulis mengatakan bahwa orang-orang yang berada di tepi sungai Danube itu bukan orang muslim (non-muslim). Penulis membuat garis pembeda yang tegas di antara orang-orang itu. Istilah yang digunakan oleh penulis untuk menegaskan perbedaan di antara mereka adalah kata "ironis". Orang-orang yang menuju masjid adalah pria-pria berbaju gamis, berjenggot, berkopiah, dan membawa sajadah atau tasbih, sedangkan orang-orang yang berada di tepi Sungai Danube adalah "para manusia berbaju minim". Gambaran orang-orang di tepi sungai tersebut lebih menyeluruh dan detail jika dibandingkan dengan orang-orang yang ada di masjid, meskipun keduanya dipandang dari jarak yang dekat. Meskipun demikian, penggambaran penulis terhadap orang-orang yang menuju dan ada di masjid tersebut bernada kekaguman. Sebaliknya, terhadap orang-orang yang berada di tepi Sungai Danube, gambaran penulis bernada sinis. Hal ini dipertegas dengan penggambaran penulis terhadap seorang kakek tua yang ada di tepi sungai dan seorang imam masjid. Perhatikan kutipan berikut.

"Aku melihat seorang laki-laki tua memakai kacamata hitam mendekati salah satu perempuan yang tengah tidurtiduran tengkurap ditemani seekor anjing. Pria tua itu menggumamkan sesuatu. Aku tak paham apa yang dia katakan. Lalu tibatiba dia menawari perempuan itu sebatang rokok. Telapak tangan perempuan itu mengibas. Dia tidak merokok. Lalu pria tua itu menggumam lagi sambil 
tersenyum sendirian. Kemudian dia mengeluarkan sesuatu dari dompetnya, kemudian dijulurkannya pada perempuan itu. Selembar uang warna hijau nominal 100 Euro. Dan kali ini perempuan muda itu merasa tersinggung. Mukanya memerah. Dia bangkit, mengambil tikar, dan menggiring anjingnya meninggalkan pria uzur itu cepat-cepat. Pria itu tersenyum lagi, menggumam sendiri. Dia menebarkan pandangan kesana-kemari, seperti mencari seseorang yang bisa didekatinya lagi” (Salsabiela dan Rangga, 2011: 113).

Gambaran tersebut adalah tentang seorang lelaki yang berada di tepi Sungai Danube. Pengamatan dilakukan penulis dengan jarak yang sangat dekat dan intens. Ia menggambarkan dengan detail segala gerakgerik yang dilakukan oleh lelaki tersebut: menggumam, tersenyum, mengeluarkan sesuatu dari dompet, menyodorkan uang berwarna hijau nominal 100 Euro. Penulis juga menggambarkan dengan detail si perempuan: tersinggung dengan muka yang memerah. Gambaran yang hanya bisa dilakukan dengan pengamatan jarak pandang sangat dekat. Akan tetapi, gambaran tersebut bukanlah gambaran yang menyenangkan bagi penulis. Lelaki itu adalah ancaman. Meskipun tidak mengalami hal yang sama, Hanum merasakan ketersinggungan seperti perempuan itu. Bagi Hanum, tepian Danube yang asri, teduh, dan penub kedamaian itu ternyata menyimpan bahaya tersendiri (Salsabiela dan Rangga, 2011: 113). Gambaran lelaki tersebut berbeda dengan gambaran seorang imam masjid yang ada di Masjid Besar Wina.

"Suara lembut dari imam Vienna Islamic Center tadi seketika mengguyur panasnya hatiku dengan aliran air jernih. Empunya suara adalah imam masjid yang kurang lebih berusia 60 tahun ke atas; seumuran dengan pria jail tadi. Kupandangi dari jauh bangku di tepi sungai yang tadi kududuki. Pria tua bangka tadi sudah tidak berada di sekitar sana. Dia mencari mangsa lain. Seorang perempuan berbikini yang tengah duduk bersandar di pohon didekatinya.
Aku tak tahu apa yang terjadi setelah itu" (Salsabiela dan Rangga, 2011: 114).

Gambaran yang diberikan oleh penulis tentang imam masjid tersebut tidak banyak, cenderung sekilas, tetapi bernada kagum, mengguyur hati yang panas atas ulah lelaki yang ada di tepi sungai. Dalam deskripsi itu bahkan Hanum secara terang-terangan membandingkan laki-laki di tepi sungai dengan sang imam. Sang lelaki di tepi sungai adalah sumber ancaman, sedangkan sang imam adalah sumber kedamaian.

Penggambaran yang menggunakan perbandingan juga terlihat pada orang-orang yang berada di Masjid Besar Paris.

"La Grande Mosquee de Paris atau Masjid Besar Paris hari itu begitu ramai tak hanya jemaah shalat yang berdatangan. Sejumlah turis kulihat berlalu lalang sambil menjepret sana-sini dalam kompleks masjid. Ada hal yang sangat kuhargai. Meski hawa hari itu sedikit terik, tak kulihat para turis perempuan berbaju minim dan seksi" (Salsabiela dan Rangga, 2011: 190).

"Bukan hanya masjidnya yang ramai, kafe dan restoran dalam kompleks masjid ini pun tampak sesak dipenuhi pengunjung. Dari dandanan mereka, sepertinya mereka bukan orang yang menunaikan shalat di masjid saja. Sebagian besar justru turis dan orang lokal yang ingin menikmati menu Timur Tengah di kafe ini”" (Salsabiela dan Rangga, 2011: 190).

Gambaran tersebut adalah gambaran yang objektif dan diamati dengan jarak pandang dekat. Penulis memperlihatkan siapa saja orang-orang yang berada di dalam masjid itu. Orang-orang yang mendatangi masjid tersebut bukan hanya orang yang hendak melakukan shalat, melainkan juga orang yang hanya berniat mengunjungi dan memotret masjid (turis). Orang-orang yang kedua itu adalah orang-orang non-muslim. Yang diperhatikan oleh penulis dari turis-turis itu adalah penampilan fisiknya. Apa yang membahagiakan bagi penulis adalah 
para turis tersebut tidak menggunakan pakaian yang minim seperti yang dilakukan orang-orang yang berjemur di tepi sungai Danube.

\begin{abstract}
"Aku melihat sekeliling masjid. Begitu banyak turis bule yang duduk-duduk di dalam masjid. Ternyata mereka yang masuk ke masjid tak harus menggunakan tudung kepala. Hanya pakaian rapi dan terhormat syaratnya. Saat sholat berjamaah digelar, para turis yang sebagian besar nonmuslim tersebut dilokasikan di pinggir dalam masjid. Usai shalat, masjid ini seolah menjadi milik semua orang, bagiku dan bagi mereka yang tak memeluk Islam" (Salsabiela dan Rangga, 2011: 341).
\end{abstract}

Gambaran terhadap para turis yang ada di sekitar Masjid Biru ini serupa dengan gambarannya terhadap para turis yang ada di masjid Besar Paris. Secara tersirat, yang diperhatikan adalah para turis perempuan. Perhatian terhadap mereka hanya ditujukan pada penampilan fisiknya dan sekilas saja. Gambaran tersebut berbeda dengan gambarannya terhadap perempuan-perempuan muslim yang ada di dalam Masjid Biru.

\section{Penggambaran Subjektif dalam 99 Cahaya di Langit Eropa}

Di samping pengamatan yang objektif, penulis tidak dapat melepaskan diri dari pengamatan yang melibatkan diri dan perasaanperasaanya yang mengarah pada penggambaran subjektif. Strategi subjektif tampak lebih dominan digunakan oleh penulis. Subjektivitas tersebut ada yang diungkapkan secara terangterangan (subjektif eksplisit), tetapi juga ada yang bersembunyi dibalik yang objektif (subjektif implisit).

Meskipun awalnya Bukit Kahlenberg digambarkan secara objektif, terdapat beberapa penggambaran yang menunjukkan subjektivitas penulis sebagaimana terlihat pada kutipan berikut.
"Aku berusaha menikmati keindahan sore di Kahlenberg. Sampai aku tersadar ada sesuatu yang hilang pada senja itu. Sesuatu yang akrab kudengar menjelang matahari terbenam, tapi kali ini tiada" (Salsabiela dan Rangga, 2011: 32).

"Konsentrasiku kupusatkan pada satu kata, seolah aku mendengarnya dengan jelas, dan mengikutinya. Allahu akbar... Allabu Akbar... Begitulah rasanya. Lalu kuresapi hafalan doa seusai panggilan shalat. Sebersit perasaan rindu kampung halaman karena rindu adzan tiba-tiba menerpaku. Sudah beberapa minggu telingaku tak dihampiri suara kebesaran Tuhan di Eropa ini" (Salsabiela dan Rangga, 2011: 33).

Ketika mendeskripsikan senja yang indah di Kahlenberg, bagi penulis masih ada yang kurang pada senja tersebut. Kekurangan itu disebabkan ada sesuatu yang dirindukan oleh penulis, yaitu suara adzan. Ketika adzan tidak didengar, seberapapun memikatnya senja di Kahlenberg, suasana itu menjadi tidak berarti. "Ada sesuatu yang hilang" di Kahlenberg itu. Adanya sesuatu yang hilang tersebut adalah subjektivitas penulis karena ia tidak mendengar sesuatu yang biasa didengarnya. Hal itu menyebabkan penulis berkhayal akan adanya adzan dan menjadikannya rindu terhadap kampung halamannya. Dengan demikian, gambaran penulis mengenai senja yang ada di Kahlenberg tersebut melibatkan subjektivitas dirinya.

Gambaran subjektif juga terlihat ketika penulis berada di dalam museum. Sebagai contoh perhatikan kutipan berikut.

"Pasalnya, museum Eropa didesain berkesan angker dengan cahaya remangremangnya. Dan itulah yang terjadi di museum Wina; cahaya redup remangremang membuat ruang museum makin berkesan mistis. Apalagi jika kita sendirian di ruangan tersebut. Ruang seakanakan bernuansa magis berkat kehadiran benda-benda keramat berupa patung manusia atau lukisan wajah yang berumur 300 hingga 500 tahun" (Salsabiela dan 
Rangga, 2011: 73).

"Bayangkan, ruang sebesar ini hanya dinaungi tiga atau empat lampu ayun yang berkelebat-kelebat karena gerakan udara. Kelebatan itu membuat wajahwajah dalam lukisan atau patung-patung manusia berkesan hidup dan bergerakgerak” (Salsabiela dan Rangga, 2011: 73).

"Tiba-tiba aku teringat, di dekat pintu masuk lantai dua ada beberapa figur topeng kematian atau yang biasa dikenal dengan death mask. Death mask adalah tradisi bangsa Eropa untuk membuat cetakan topeng wajah orang-orang besar yang baru saja meninggal. Hal ini dilakukan untuk mengabadikan damainya wajah kematian orang tersebut sebelum dia dikubur" (Salsabiela dan Rangga, 2011: 75-76).

"Angker", "mistis", dan "magis" adalah kesan-kesan yang diberikan oleh penulis terhadap ruangan dalam museum tersebut. Kesan-kesan tersebut melibatkan diri penulis. Penulis memberikan kesan tersebut berdasarkan pengalaman personalnya. Yang objektif di ruangan tersebut adalah "tiga atau empat lampu" dan "lukisan atau patung manusia", sedangkan kesan "hidup dan bergerak-gerak" serta "seram" adalah khayalan-khayalan penulis semata. Kutipankutipan tersebut memperlihatkan bahwa subjektivitas penulis berperan sangat dominan dalam menggambarkan benda-benda dan kondisi yang melingkupinya. Yang terdapat di ruangan itu adalah lukisan manusia, patung baju zirah, dan death mask. Selebihnya hanyalah fantasi penulis. Penggambaran yang demikian itu cukup banyak dilakukan oleh penulis.

Sejumlah penafsiran juga dilakukan oleh penulis ketika dirinya melihat beberapa lukisan yang ada di museum. Penggambaran yang subjektif ini terlihat lebih dominan dibandingkan penggambaran objektifnya. Perhatikan kutipan berikut.

"Lukisan raja, panglima perang, atau tokoh penting biasanya dilukis dengan penuh kegagahan. Menunjukkan kesaktian, kekuatan, dan intelektualitas dengan penanda tongkat, buku, atau mahkota sebagai simbolnya. Tapi pria ini dilukiskan seperti kakek-kakek. Tua dan lemah. Lama-lama terlihat seperti seorang penjahat. Atau seorang pecundang. Matanya nanar, mengiaskan kegagalan luar biasa dalam hidupnya" (Salsabiela dan Rangga, 2011: 78).

"Lukisan itu lama-lama memiliki batin yang dalam. Seakan-akan mata Mustafa menyaksikan langsung seorang cicit keturunannya yang terisak-isak di depan hidungnya tanpa dia bisa berbuat apaapa. Mustafa hanya diam membisu. Dia tak bisa merangkul cucunya, tak bisa "membesarkan hati" cucu keturunannya. Matanya kosong melompong" (Salsabiel dan Rangga, 2011: 80).

"Mustafa tak memiliki harkat untuk membela diri dari penghakiman cucunya. Dia pasrah mendengarkan semua kekecewaan yang dituturkan Fatma. Sejurus aku merasakan sebuah situasi yang menghanyutkan hati dan perasaanku. Sebuah perasaan yang tiada terperi. Di bumi Eropa, Kara Mustafa jelas dianggap penyerang. Di tanah air pun dia dikenang sebagai pecundang karena tidak mati di medan perang" (Salsabiela dan Rangga, 2011: 84).

"Semua atribut kebesaran yang ada di lukisan itu tiba-tiba sirna, seiring dengan wajah Mustafa yang redup seketika. Lukisan itu tadi masih bernyawa. Kini begitu seluruh lampu dipadamkan, ruh Mustafa sudah tidak ada di sana lagi" ( Salsabiela dan Rangga, 2011: 84).

Kutipan-kutipan di atas adalah gambaran terhadap lukisan Kara Mustafa. Gambaran tersebut sudah melibatkan penilaian dan penafsiran penulis. Ia menilai bahwa lukisan tersebut terlihat lemah dan seperti penjahat. Dalam lukisan tersebut, kegagahan Mustafa hanya ditampilkan pada pakaiannya, bukan pada ekspresi wajahnya. Wajah Mustafa adalah wajah yang tua dan lemah, wajah seorang penjahat atau seorang pecundang. Namun, pernyataan-pernyataan itu terlihat rancu. Di 
satu sisi, dikatakan bahwa lukisan itu memiliki batin yang dalam. Lukisan itu juga bernyawa. Di sisi lain, mata lukisan itu kosong melompong, tak bergairah, yang menunjukkan keringnya jiwa, tidak hidup. "Keburukan” Mustafa bukan berasal dari dirinya sendiri, tetapi karena ada yang menjadikannya buruk. Wajah dalam lukisan itu redup karena lampu yang dipadamkan, bukan karena wajah itu redup dalam dirinya sendiri. Mustafa dianggap sebagai pecundang bukan karena menyerang Eropa, tetapi karena tidak mati di medan perang. Pernyataan ini adalah pernyataan penulis yang tidak akurat. Pada bagian sebelumnya (hlm.83) dikatakan bahwa Mustafa mati di medan perang, sedangkan pada bagian setelahnya (hlm. 84) dikatakan bahwa Mustafa tidak mati di medan perang. Lukisan Mustafa ini mendapatkan perhatian yang dominan dibandingkan dengan benda-benda yang lain di Museum Kota Wina. Bahkan, tidak terdapat lukisan lain yang diperhatikan oleh penulis selain lukisan Kara Mustafa.

Ingatan tentang tanah asal juga tampak dominan ketika penulis mendeskripsikan sesuatu yang ditemuinya, di antaranya ialah ketika ia berkunjung di restoran Deewan. Deewan adalah restoran ala Pakistan dengan sistem pembayaran "seikhlasnya". Pembeli boleh tidak membayar apa yang dimakannya atau membayar sesuai "keikhlasannya". Aturan yang diberlakukan di restoran ini berbeda dengan restoran-restoran lain di Wina. Ketika pertama kali melihat plang restoran itu, seketika ingatan Hanum melayang ke tanah asalnya.

"Kalau di Jakarta pasti sudah bangkrut." Itu komentar pertama Rangga membaca restoran tersebut. Aku sepakat dengan Rangga. Di Jakarta, tak kurang dari seminggu, restoran seperti itu pasti bubar jalan. Membayangkan para sopir bus dan angkot, pedagang asongan, dan pengangguran akan menyerbu tempat itu. Menjadikannya markas dan tempat tongkrongan sehari-hari. Sudah bisa ditebak seperti apa nasib restoran itu".
Menurut penulis, aturan yang diberlakukan oleh restoran Deewan tidak akan dapat diterapkan di tanah asalnya. Dalam hal ini, penulis menempatkan orang Indonesia dan orang Eropa dalam posisi yang berseberangan. Orang-orang Indonesia (Jakarta) berbeda dengan orang-orang Eropa. Orang Indonesia rakus dan tidak tahu aturan, sedangkan orang Eropa sangat beradab. Restoran Deewan tidak akan mengalami kebangkrutan karena orangorang Eropa jujur dan dapat mengendalikan diri. Sebaliknya, jika restoran Deewan itu bertempat di Indonesia, restoran itu tidak akan dapat bertahan lama. Pandangan yang demikian itu adalah pandangan yang subjektif karena melibatkan penilaian-penilaian penulis.

Selanjutnya adalah penafsiran terhadap Axe Historique. Axe Historique adalah sebutan untuk bangunan-bangunan yang berada dalam satu garis lurus di Paris (air mancur besar, monumen Obelisk Mesir, jalan Champs-Elysees, dan monumen Arc de Triomphe). Penafsiran terhadap Axe Historique ini bertumpang tindih dengan ingatan akan tanah asal dan inferioritas penulis. Perhatikan kutipan berikut.

"Sesaat baru kusadari, pemandangan 'satu garis' ini begitu indah. Aku pernah melihat tata kota yang mirip seperti ini di kota kelahiranku, Yogyakarta. Konon katanya, singgasana sultan, Siti Hinggil Kraton Yogyakarta, Jalan Malioboro, Monumen Tugu, dan Gunung Merapi juga berada dalam satu garis. Artinya, jika Sultan duduk di singgasananya, dia bias melihat Malioboro, Tugu, dan Gunung Merapi tepat pada satu garis. Namun, seiring dengan tumbuhnya mal dan bangunan baru di sekitar Malioboro yang juga diperparah polusi kota, garis lurus ini semakin susah dibuktikan secara kasat mata” (Salsabiela dan Rangga, 201: 174).

“Sebaliknya, pemandangan 'garis lurus' yang kulihat di Paris ini begitu istimewa. Garis ini jelas terlihat karena banyak bangunan luar biasa lainnya yang terletak dalam satu garis. Aku berisi di bawah lengkungan Monumen du Carrousel, jalanan berkerikil putih tepat simetris 
membelah rumput-rumput di Taman Tuileries. Di ujung taman aku melihat lingkaran besar kolam air mancur, lalu tepat di belakang pusat lingkaran itu berdiri megah Monumen Mesir berbentuk pensil setinggi 20 meter lebih. Jauh di belakang kulihat Monumen Arc de Triomphe de I'Etoile yang terhubung oleh jalan Champs-Elysees, pusat perbelanjaan paling terkenal di Paris. Ketika aku melongok ke belakang, puncak Piramida Louvre yang tepat berada di garis tersebut" (Salsabiela dan Rangga, 2011: 175).

Ketika pertama kali melihat Axe Historique, yang terlintas dalam benak penulis adalah gambaran mengenai sesuatu yang serupa di tanah asalnya. Gambaran mengenai tanah asal tersebut disajikan dengan sikap kecewa dan merendahkan. Sebaliknya, gambaran mengenai Axe Historique disajikan dengan detail dan penuh kekaguman. Gambaran ini digunakan untuk menunjukkan betapa penulis sangat mengagumi Axe Historique. Apa yang terjadi di Yogyakarta adalah kesemerawutan, sedangkan di Paris adalah keteraturan.

Ingatan-ingatan pada tanah asal juga dapat dilihat ketika penulis menggambarkan sistem transportasi yang ada di Paris.

"Rasanya langsung ciut hatiku mengingat Jakarta. Jakarta yang terus berpikir bagaimana mengatasi kemacetan dalam kurun waktu 20 tahun terakhir, namun tetap saja nihil hasilnya" (Salsabiela dan Rangga, 2011: 143).

"Berbekal niat suci menjadi agen pengurang kemacetan Jakarta, aku menggunakan Trans Jakarta. Tapi niat baikku jadi warga yang baik sirna begitu saja. Seorang perempuan menjambak rambutku karena bernafsu menyerobot masuk ke dalam bus. Kursi kosong di dalam bus bagaikan harta karun tak bertuan bagi siapa saja yang malas atau tak kuat berdiri di tengah desakan penumpang lain. Tanda utamakan tempat duduk untuk ibu hamil, orang tua, dan orang cacat di dalam bus hanya menjadi tempelan pemanis" (Salsabiela dan Rangga, 2011: 186).

Penulis menempatkan Eropa dan tanah asalnya sebagai dua wilayah yang memiliki kondisi yang berbeda. Eropa adalah wilayah yang unggul dengan segala sistemnya, sedangkan tanah asalnya sebaliknya. Eropa teratur, sedangkan Jakarta tidak teratur. Kalaupun Eropa memiliki kondisi yang sama dengan Jakarta, sistem yang dibangun lebih unggul. Yang tidak dimiliki oleh Jakarta (Indonesia) jika dihadapkan dengan Eropa adalah disiplin waktu. Hanum menganggap bahwa hal itulah yang membuat Jakarta tidak mampu seunggul Eropa.

Gambaran yang subjektif secara eksplisit diperlihatkan Hanum ketika ia mendeskripsikan suasana yang ada di luar bandara Sabiha Gocken. Kondisi luar bandara itu mengingatkan penulis pada kondisi yang ada di bandara Indonesia. Secara spesifik, Hanum menyebutkan bahwa kondisi di luar bandara Sabiha Gocken serupa dengan Bandara Soekarno-Hatta. Perhatikan kutipan berikut.

"Begitu keluar bandara, kami serasa berada di Bandara Soetta Cengkareng. Parkir taksi, bus, dan mobil pribadi centang perenang. Penjemput dan orang yang berdatangan dari penerbangan berseliweran tak tentu arah. Atmosfer demikian diperparah dengan hujan yang turun lebat. Para penjaja taksi yang melihat kami bingung langsung menyerbu satu per satu. Kami terus menggeleng, sambil melangkahkan kaki menuju bus besar bernama Havas yang terparkir tepat di depan billboard bertuliskan "Istanbul, The European Capital of Culture". Di dekatnya ada papan besar lain ber-tagline "Turkey Welcomes You" dengan ikon bunga tulip. Bus Havas adalah semacam bus Damri di bandara Cengkareng yang mengantar penumpang dari bandara ke pusat kota" (Salsabiela dan Rangga, 2011: 325).

Kutipan di atas pun memperlihatkan bahwa yang dibandingkan oleh penulis selalu 
terkait dengan ketidakberesan yang ada di tanah asal. Penulis, misalnya, tidak membandingkan kondisi di dalam bandara Sabiha Gocken dan kondisi di dalam bandara Soetta. Artinya, dalam hal ketidakberesan, Istanbul dan Jakarta adalah serupa. Orang-orang di Istanbul dan Jakarta tidak dapat bertindak teratur, lamban, dan lain sebagainya. Terjadi ikatan yang kuat antara Hanum dan tanah asal sehingga beberapa kondisi yang terdapat di Istanbul mengingatkan Hanum akan tanah asalnya.

Beberapa gambaran yang subjektif juga dapat dilihat ketika penulis pertama kali menginjakkan kaki di Cordoba. Perhatikan kutipan di bawah ini.

"Kupandang jalanan di bawahku yang membentuk labirin dan rumah-rumah dengan eksterior sangat serasi di sekitar Mezquita. Belasan abad lalu pastilah manusia berbondong-bondong keluar dari rumah tersebut, lalu memenuhi jalanan yang ciut menuju satu tempat, Mezquita. Meski berbentuk labirin dan berkelokkelok, mereka tidak akan bingung kemana mencari tempat peribadatan itu karena semua orang berbondong-bondong menuju tempat yang sama pada subuh seperti ini" (Salsabiela dan Rangga, 2011: 245).

"Lagi-lagi hanya ilusi. Fantasi liarku yang merindukan harapan, merindukan kembalinya nostalgia Cordoba masa lalu. Kenyataannya pagi ini dari jendela kamar penginapanku, aku hanya melihat jalan setapak yang sempit di bawah sana kosong melompong" (Salsabiela dan Rangga, 2011: 243).

Seperti halnya Cordoba, kekecewaan penulis terlihat sangat menonjol ketika melihat Mezquita yang tak lagi digunakan sebagai masjid. Kekecewaan tersebut berulang-ulang terlihat dalam beberapa deskripsinya.

"Bagiku, Mezquita ini tetaplah sebuah tempat yang agung. Meskipun secara fisik dia bukan lagi rumah ibadah bagi agamaku. Sejarah memang telah terjadi, mengubahnya menjadi tempat lain yang sama sekali berbeda. Tapi, bagiku sendiri tempat ibadah ini tidak pernah berubah, sampai kapanpun tetaplah masjid" (Salsabiela dan Rangga, 2011: 255).

"Ukiran yang berwarna hitam dan kuning itu bersambung-sambung. Aku dan Rangga terpana. Kedua tangan kami menggenggam erat jeruji. Mata kami tak berpaling dari tulisan-tulisan Arab itu. Tiba-tiba hatiku berdesir, jiwaku luruh, permukaan kulitku merinding. Hatiku seperti berontak kuat menghadapi realitas dalam bangunan ini. Adakah yang bisa mengatakan padaku...ini bukan gereja... ini masjid?" (Salsabiela dan Rangga, 2011: 262).

Kutipan-kutipan di atas memperlihatkan bahwa subjektivitas penulis terlihat sangat dominan ketika menanggapi Mezquita. Penulis tidak rela jika Mezquita menjadi gereja. Yang dicari adalah keagungan Mezquita, kejayaan Cordoba yang merupakaan kejayaan Islam di Eropa. Namun, apa yang terjadi pada saat ini jauh berbeda dengan apa yang diinginkan. Mezquita, yang awalnya adalah sebuah masjid, telah dialihfungsikan menjadi sebuah gereja. Akan tetapi, dengan bergantinya Mezquita menjadi gereja, hal itu tidak menjadikan penulis berhenti mengagungkan Mezquita. Baginya, Mezquita tetaplah tempat yang agung. Bahkan, meskipun telah diubah menjadi gereja, Mezquita tetaplah dianggap sebuah masjid.

Di samping gambaran subjektif yang penuh dengan kekecewaan tersebut, penulis juga menyajikan gambaran subjektifnya yang bernada kekaguman. Sebagai contoh, perhatikan kutipan berikut.

"Hagia Sophia, mendengar namanya saja kita sudah bisa membayangkan sesosok putri nan anggun. Demikian pula Hagia Sophia, dia tak lekang oleh zaman dan ruang, meski berkali-kali ditempa gempa bumi dan pengambilalihan kekuasaan dari satu tangan ke tangan yang lain. Dia tetap suci" (Salsabiela dan Rangga, 2011: 334). 
"Sebagai muslim, aku dan Rangga terpana menyaksikan 4 medalion raksasa berwarna hitam yang sungguh menggetarkan hati. Persis getaran hati kami saat memandang Al-Hambra dan Mezquita" (Salsabiela dan Rangga, 2011: 335-336).

Hagia Sophia tidak hanya digambarkan secara objektif, tetapi juga diikuti dengan gambaran subjektifnya. Gambaran subjektif tersebut memperlihatkan kekaguman pada Hagia Sophia. Secara eksplisit penulis menyebutkan bahwa kebanggannya terhadap medalion yang ada di dalam Hagia Sophia adalah status dirinya "sebagai muslim", bukan sebagai turis. Hal ini menunjukkan subjektivitasnya lah yang dominan ketika menilai sesuatu hal.

Gambaran yang subjektif juga terlihat pada pengamatan terhadap orang-orang. Perhatikan kutipan berikut.

"Seorang bapak tua berbadan gelap keluar dari kedai yang kumuh itu. Dia mengeluarkan sebongkah daging yang cukup besar, lalu meletakkannya di meja di luar kedai. Kemudian dengan cekatan Pak Tua itu menghunuskan pisau besar dari balik sakunya. Dengan sekuat tenaga dia memotong-motong bongkahan daging itu menjadi beberapa bagian. Dalam beberapa menit saja gumpalan daging babi yang cukup besar tadi sudah menjadi kepingan-kepingan kecil" (Salsabiela dan Rangga, 2011: 248).

Kutipan di atas adalah gambaran tentang Hassan. Seorang muslim yang berjualan babi di sekitar Mezquita. Meskipun berjualan babi, Hassan tidak pernah memakan babi. Penulis meluangkan waktu untuk berbincang cukup lama dengan Hassan. Oleh karena itu, penggambaran dilakukan penulis dengan pengamatan jarak pandang yang sangat dekat. Selain itu, dalam menggambarkan Hassan tersebut penulis tidak hanya menyajikannya dari segi penampilan fisik, tetapi juga masuk ke dalam perasaan-perasaan Hassan. Pilihan Hassan untuk berjualan babi tersebut tidak membuat penulis "membencinya". Penulis bahkan dapat memahami pilihan-pilihan Hassan.

Hubungan antara Hassan dan penulis sangat intim. Ada rasa kasihan dalam diri penulis terhadap Hassan. Namun, penulis tidak dapat berbuat apa-apa. Hal ini justru semakin "menyiksa" penulis. Bagi penulis, apa yang dilakukan oleh Hassan hanyalah percaya pada realitas. Realitas bahwa di dekat Merquita sebuah kedai mau menerimanya bekerja, meski harus berjualan babi. Dia tak peduli lagi. Desakan ekonomi membuatnya menutup mata (Salsabiela dan Rangga, 2011: 251). Selanjutnya adalah gambaran penulis tentang seorang perempuan Yahudi.

"Begitu turun dari lift, aku menemukan
seseorang. Seseorang yang selama ini
kucari-cari. Perempuan berkerudung.
Perempuan itu tampak sedang
menjalankan tugasnya pada pagi hari.
Sangat pagi, sebelum tamu penginapan
beranjak keluar. Dia tampak mengelap
semua perabotan dan ornamen-
ornamen di lantai lobi. Termasuk
patung Maimonides yang menjadi ikon
penginapan ini" (Salsabiela dan Rangga,
2011: 244).

Awalnya, perempuan itu oleh penulis dianggap sebagai seorang muslim karena mengenakan penutup kepala. Penulis memberikan salam kepada perempuan itu, tetapi tidak dijawab. Perempuan itu hanya menoleh dan tersenyum. Setelah memberikan salam lagi dan tidak dijawab, penulis baru menyadari bahwa perempuan itu bukan seorang muslim, tetapi seorang Yahudi yang memang memiliki kebiasaan mengenakan penutup kepala. Penulis pun tidak menyalahkan mengapa perempuan itu tidak membalas salamnya, tetapi ia justru menyalahkan dirinya sendiri.

"Kulihat perempuan berkerudung tadi tersenyum lagi. Aku membalas senyumnya sekaligus berusaha menghilangkan rasa malu yang tiba-tiba menjalar. Dia lalu meninggalkan kami masuk ke dalam bilik "staff only" di belakang meja resepsionis" (Salsabiela dan Rangga, 2011: 244). 
"...aku baru menyadari perempuan itu mengenakan kerudung yang tidak bisa disebut jilbab. kerudung itu juga dipadukan dengan setelan rok pendek dan kaos kaki putih setinggi lutut. Sepatunya seperti sepatu para pengibar bendera pusaka 17 Agustus. Gaya busana perempuan Yahudi konservatif yang sering kutemui di Eropa" (Salsabiela dan Rangga, 2011: 245).

Pengamatan yang dilakukan oleh penulis terhadap perempuan itu dilakukan dengan jarak pandang yang sangat dekat. Penulis bahkan menganggap bahwa perempuan itu—karena senyum yang diberikan—sebagai saudaranya. Dalam hal ini, subjektivitas penulis muncul karena ia menganggap perempuan itu terkoneksi dengan dirinya.

"Aku tiba-tiba menyadari, bisa saja perempuan itu paham aku menganggapnya sebagai saudara muslim. Walaupun ternyata aku salah. Namun, senyumnya barusan telah mematahkan sekat-sekat pembatas persaudaraan. Kau dan aku berbeda, tapi senyuman kita bermakna sama” (Salsabiela dan Rangga, 2011: 246).

Jika penggambaran penulis terhadap Hassan dan Perempuan Yahudi tersebut tampak intim, lain halnya dengan gambarannya terhadap Gomez, seorang pegawai hotel yang menjemput dan mengantarkan penulis ke hotel di Cordoba.

"Aku terguncang-guncang sepanjang perjalanan karena kepotan mobil Gomez ke sana kemari. Sebagai tamu, kami merasa tidak dihargai. Anak muda seolah tak menyadari ada nyawa yang tengah dia pertaruhkan dalam mobil, demi mendengarkan laga siaran sepakbola Spanyol melawan Portugal!" (Salsabiela dan Rangga, 2011: 236).

Pengamatan penulis dilakukan dengan jarakpandang sangatdekat karena mereka berada dalam satu mobil. Hal tersebut menjadikan penulis dapat menggambarkan tingkah laku Gomez dengan detail. Gomez adalah seorang pemuda yang sangat fanatik terhadap klub sepakbola Spanyol. Tindakannya di dalam mobil itu membuat penulis tidak nyaman. Penulis bahkan merasa tidak dihargai sebagai tamu. Dengan kata lain, Gomez digambarkan sebagai seorang yang brutal, berlaku seenaknya, dan tidak menghargai orang lain.

"Dia tidak menjelaskan apa keyakinannya. Bagi Gomez, keyakinan tentang agama itu tidak penting. Lebih penting Spanyol menang atau kalah dari Portugal malam itu. Gomez pun langsung berteriak kencang begitu mendengar buncahan suara orang-orang dari kafe dan bar" (Salsabiela dan Rangga, 2011: 238-239).

Terdapat suatu momen ketika penulis menanyakan kepada Gomez apakah dia seorang muslim atau bukan-karena Gomez sempat mengucapkan salam yang identik dengan umat Islam kepada Hanum. Menurut pengamatan Hanum, kakek buyut Gomez adalah seorang muslim. Sementara itu, bagi Gomez, keyakinan tentang agama itu tidak penting (Salsabiela dan Rangga, 2011: 233). "Kemarahan" penulis terhadap Gomez lebih disebabkan oleh tindakannya yang sembrono, bukan karena Gomez tidak menganggap penting agama.

Selain Gomez, penulis juga menggambarkan seseorang yang mirip dengan Gomez, yaitu Sergio. Dia adalah seorang tour guide di sekitar Mezquita.

"Entah mengapa, aku punya firasat bahwa Sergio bisa membagi cerita-cerita yang jauh lebih menarik daripada info dari buku wisata (Salsabiela dan Rangga, 2011: 269).

Dari caranya mengawali tur ini, aku langsung yakin Sergio memang benarbenar tour guide profesional. Kami berjalan berdampingan menapaki jalan yang terbuat dari lapisan batu kotak. Tak terasa, kami pun semakin menjauhi Mezquita" (Salsabiela dan Rangga, 2011: 271). 
"Aku mengangguk-angguk. Aku tibatiba merasa sangat cocok dengan Sergio. Meskipun dia bukan muslim, aku merasa apa yang dia katakan tidak bermaksud hanya menyenangkan hati kami sebagai "tamu"-nya. Aku tahu Sergio akan berkata jujur dan tidak mengada-ada karena itu memang fakta. Hatiku mulai tergugah, mulai mendapatkan ruh dari kota masa lalu ini setelah mendengar penjelasannya tadi. Betapa Islam sangat menghormati pemeluk agama lain" (Salsabiela dan Rangga, 2011: 274).

Kutipan-kutipan di atas menunjukkan bahwa keterlibatan antara penulis dan Sergio sangat intim. Pengamatan penulis jelas menggunakan jarak pandang yang dekat. Sergio menceritakan sejarah kecemerlangan peradaban Islam di Cordoba yang membuat penulis semakin mengagumi Cordoba dan juga Sergio sendiri. Bahkan secara eksplisit penulis mengungkapkan kecocokannya dengan Sergio.

Meskipun Sergio bukan orang Islam, Sergio pun mengungkapkan kekagumannya pada peradaban Islam. Penulis meyakini bahwa kekaguman Sergio itu bukan disebabkan oleh profesinya sebagai seorang guide yang punya kecenderungan untuk menyenangkan tamu. Kesan penulis terhadap Sergio ini berbeda jauh dengan kesannya terhadap Gomez. Sergio adalah seseorang yang tidak percaya terhadap agama. Menurut Sergio, pada dasarnya manusia tak pernah benar-benar membela agamanya. Sergio adalah seorang agnostik, orang yang percaya terhadap Tuhan, tetapi tidak mempercayai agama. Namun, Sergio percaya bahwa Tuban dan uang adalab penyelamat hidupnya. Hal tersebut membuat penulis kecewa. Penulis merasa lebih beruntung daripada Sergio karena kepercayaannya terhadap agama Islam.

Dibandingkan dengan subjektivitas yang eksplisit, subjektivitas implisit dalam gambaran penulis sangat minim. Meskipun demikian, gambaran ini menjadi signifikan. Subjektif implisit terlihat ketika penulis berupaya untuk menggambarkan atau mendeskripsikan sesuatu secara objektif, tetapi di dalamnya tersembunyi subjektivitasnya. Gambaran tersebut, misalnya, dapat dilihat ketika penulis menggambarkan gereja St Charles.

"Orang Indonesia yang melihat gereja itu bisa salah sangka. Dari kejauhan aku langsung menganggapnya masjid. Ternyata ada salib yang bertengger di atas kubahnya. Mengingatkanku kembali bahwa aku tengah berada di benua Eropa yang mayoritas penduduknya beragama Kristen. Tidak mungkin aku bisa melihat masjid semegah itu tepat di jantung kota" (Salsabiela dan Rangga, 2011: 70).

"Gereja baroque St Charles di sebelah Museum Kota Wina itu kupandang lekatlekat. Dia memang hanya bangunan fisik mati. Dia hanya sekilas seperti masjid. Dan selama dia adalah gereja, takkan pernah ada suara muadzin yang melantunkan kalimat Allah dari puncak menaranya" (Salsabiela dan Rangga, 2011: 71-72).

Gambaran tersebut seolah objektif, tetapi tersembunyi kekecewaan karena menara tersebut bukanlah menara masjid, tetapi menara gereja. Dalam deskripsi itu terdapat kekecewaan sekaligus harapan bahwa apa yang dilihatnya adalah masjid. Hal yang senada juga terlihat pada kutipan berikut.

"Sepagi itu di Cordoba, belum ada satu pun toko atau kedai yang buka. Pintu-pintu gerbang dari rumah-rumah bersusun yang mengitari Mezquita juga masih tertutup rapat. Pintu-pintu itu seperti melarang bekas kaleng dan botol bir sisa semalam memasuki pelatarannya. Kaleng dan botol bir itu masih bertebaran di jalan-jalan seputar Mezquita" (Salsabiela dan Rangga, 2011: 247).

"Hanya ada satu kedai yang masih buka, persis di sudut belokan menuju Mezquita. Kedai itu menggelar barang dagangan yang tak biasa bagi penglihatanku. Deretan daging paha yang gemuk-gemuk menggantung di kaca pajang kedai. Di atas kaca tampak bagian-bagian lain daging, mulai kulit, kepala, hingga jeroannya" (Salsabiela dan Rangga, 2011: 247). 
Deskripsi di atas terlihat objektif, tetapi tidak sepenuhnya. Di dalamnya tersembunyi juga subjektivitas. Penulis merasa kecewa karena tidak ada orang yang bangun pagi dan ramai-ramai mengerjakan sholat subuh. Selain itu, ia pun kecewa karena yang justru dilihatnya adalah botol dan kaleng bir yang bertebaran, juga kedai-kedai yang menjual daging babi. Hal tersebut adalah pemandangan yang tidak diinginkan penulis. Hal itu juga terlihat pada pembandingan Hagia Sophia dan Mezquita.

"Nasib Hagia Sophia berkebalikan dengan Mezquita di Cordoba. Hagia Sophia adalah Katedral Byzantium terbesar di Eropa yang kemudian menjadi masjid. Masjid itu memajang kaligrafi Allah, Muhammad, serta kalimat-kalimat ayat suci, tetapi tetap membiarkan lukisanlukisan Yesus dan Maria serta elemenelemen kekristenan bertengger di sana" (Salsabiela dan Rangga, 2011: 335).

"Masjid biru ini memang biru sesuai namanya. Alih-alih menghancurkan katedral Hagia Sophia, Sultan Ahmed malah membangun Masjid Biruini, seolaholah dia ingin mengatakan peradaban Islam juga tak kalah dengan peradaban Byzantium. Masjid ini dibangun tepat di depan Hagia Sophia dengan ukuran yang jauh lebih besar" (Salsabiela dan Rangga, 2011: 340_341).

Penulis membuat perbandingan antara Mezquita yang ada di Cordoba dan Hagia Sophia di Istanbul. Yang tersirat dari kutipan pertama adalah penulis bangga dengan Sultan Islam yang membiarkan Hagia Sophia sebagaimana aslinya, tidak merusak lambang-lambang Kristiani yang ada di dalamnya. Itu artinya, para pemimpin Islam waktu itu sangat menghargai perbedaan antarpemeluk agama. Mereka tidak berlaku keji terhadap pemeluk agama lain. Hal tersebut berkebalikan dengan yang dilakukan Ratu Isabella dan Ferdinand terhadap Mezquita. Baik Isabella maupun Ferdinand melakukan pemaksaan agama terhadap penduduk muslim Cordoba untuk berpindah Kristen.

\section{Kesimpulan}

Secara keseluruhan penulis lebih banyak menggunakan pengamatan subjektif daripada objektif. Ketika dunia belum dikenali, penulis menggunakan pengamatan yang objektif. Ketika dunia sudah dikenali, dunia itu menjadi tidak begitu asing sehingga subjektivitasnya dominan. Pengamatan selalu bergerak dari yang objektif menuju subjektif. Dalam novel ini, penggambaran objektif berjarak pandang jauh dapat dikatakan minim. Penggambaran lebih dominan pada objektif jarak pandang dekat. Beberapa tempat memang digambarkan dalam jarak pandang jauh, tetapi kemudian pengamatan bergerak menuju jarak pandang dekat. Namun, pandangan dengan jarak dekat itu tidak melulu menjadikan penulis menggambarkan objeknya dengan detail. Gambaran-gambarannya pun seringkali diiringi dengan ungkapan kekaguman.

Dalam hal tempat, penulis begitu berjarak dengan gereja. Gereja hampir selalu dipandang hanya dari jarak yang jauh. Ketika memasukinya, penulis tidak memberikan penggambaran yang memadai. Sementara itu, penulis terlihat begitu dekat dan akrab dengan masjid. Gambarangambaran terhadap masjid disajikan dengan detail. Begitu juga gambarannya terhadap museum dan istana. Akan tetapi, baik istana maupun museum itu tidak tergambarkan secara menyeluruh. Penulis hanya berfokus pada objek tertentu yang terdapat di dalamnya. Objekobjek yang diamati secara khusus tersebut awalnya digambarkan dengan objektif berjarak pandang dekat, tetapi kemudian menjadi subjektif yang eksplisit.

Penggambaran terhadap orang-orang banyak dilakukan dengan objektif berjarak pandang dekat dan subjektif. Penggambaran pada turis, meskipun dilakukan dengan jarak pandang dekat, deskripsi yang diberikan tidak terlalu detail. Ketika menggambarkan orang Islam yang taat, keberpihakan penulis tampak dalam ungkapan-ungkapan kekaguman. Sebaliknya, pada orang muslim yang- 
katakanlah-tidak taat, penulis tampak iba. Terhadap orang Yahudi, penulis tampak berusaha akrab, sedangkan pada seorang yang agnostik penggambaran cenderung sinis. $\mathrm{Hal}$ ini mengindikasikan bahwa-kecuali terhadap perempaun Yahudi- perjalanan ternyata tidak mengubah persepsi penulis terhadap orangorang yang "berbeda" dengannya.

Dalam gambaran subjektivitas implisit, yang tersirat adalah kekecewaan penulis terhadap realitas yang dilihatnya karena tidak sesuai dengan harapan. Dalam hal ini, ada dunia ideal yang diharapkan oleh penulis terhadap tempattempat yang dikunjunginya. Subjektivitas yang implisit ini mengindikasikan bahwa penulis, di satu sisi ingin bertindak bijak dengan mencoba menggambarkan sesuatu secara objektif, tetapi di sisi lain sebenarnya ia sangat subjektif.

Pola objektif-subjektif yang terbentuk itu bukanlah pola yang tanpa arti, tetapi pola yang berhubungan dengan perjalanan secara keseluruhan. Akan tetapi, pembahasan mengenai hal itu memerlukan ruang yang lebih luas lagi.

\section{Daftar Pustaka}

Faruk. 2012. Metode Penelitian Sastra; Sebuah Penjelajahan Awal. Yogyakarta: Pustaka Pelajar.

Thompson, Carl. 2011. Travel Writing. London and New York: Routledge.

Salsabiela, Hanum dan Rangga Almahendra. 2011. 99 Cahaya di Langit Eropa. Jakarta: Gramedia. 